\title{
Pengembangan Local Instructional Theory Pada Topik Pembagian dengan Pendekatan Matematika Realistik
}

\author{
Ahmad Fauzan, Yerizon, Fridgo Tasman, Rendy Novri Yolanda \\ Universitas Negeri Padang \\ fridgo_tasman@fmipa.unp.ac.id
}

\begin{abstract}
This research aimed to develop local instruction theory that is valid, practical, and effective to help elementary school students developing their mathematical problem-solving skills. Therefore a sequential activityis design on dailybasis to encourage students to develop their ability to solve mathematical problems, especially on the topic division. To achieve the goal, realistic mathematics approach was implemented to grade three elementary students in the learning process. The designed activities were validated by experts on the aspects of mathematical contents, language, didactical process based on realistic mathematical approach. Data were analyzed with descriptive statistics and parametric statistics. The validation results show that the local instruction theory was valid, and the implementation shows that the local instruction theory is practical and effective in improving students' mathematical problem-solving skills.
\end{abstract}

Keywords : Local instruction theory, Realistic mathematics education, Division

\section{PENDAHULUAN}

Berhitung adalah salah satu kemampuan dasar dalam matematika. Kemampuan ini sangat penting dimiliki oleh siswa dalam mengatasi permasalahan penjumlahan dan pengurangan sederhana. Bagi beberapa siswa, kemampuan ini dapat juga diinterpretasikan sebagai kurangnya atau lebihnya benda/objek yang menunjukkan kuantitias (Henik, 2016). Dengan menguasai kemampuan ini, siswa dapat menumbuhkem bangkan keterampilan berhitung yang sangat diperlukan dalam kehidupan sehari-hari.

Kemampuan berhitung seringkali menjadi permasalahan bagi siswa di sekolah dasar. Salah satu bagian dari kemampuan berhitung yang menjadi persoalan adalah pembagian. Pemba gian merupakan operasi hitung yang paling sulit bagi siswa sekolah dasar diantara operasi hitung lainnya yang mereka pelajari (Hasan, 2012). Lebih jauh lagi, (Antari, 2015) menyatakan bahwa 12 dari 24 orang siswa belum mencapai nilai target ketuntasan atau $50 \%$ siswa belum tuntas dalam belajar materi pembagian. Hal ini dikarenakan belum adanya implementasi pende katan pembelajaran yang sesuai dengan karak teristik siswa. Terlebih lagi, kegiatan pembela jaran yang dilaksanakan masih bersifat mekanis tik. Pembelajaran secara mekanistik, contohnya adalah hafalan, membuat peserta didik tidak bermatematika dengan baik (Tasman, Den
Hertog, Zulkardi, \& Hartono, 2011). Oleh sebab itu, diperlukan adanya suatu aktivitas pembela jaran yang membuat siswa dapat menemukan kembali konsep atau algoritma matematika. Hal inilah yang disebut dengan prinsip reinvention. Prinsip ini tidak dapat dipisahkan dari Realistic Mathematic Education, yang disingkat dengan RME (Freudenthal, 1986).

Berdasarkan permasalahan yang ditemui mengenai konsep pembagian di sekolah dasar, maka pembelajaran dengan menggunakan pende katan RME bisa menjadi alternatif penyelesaian. Hal ini juga didukung oleh penelitian-penelitian terdahulu yang menggunakan pendekatan RME dalam pembelajaran baik di kelas sekolah dasar maupun di universitas, seperti penelitian yang dilakuan oleh Syafriafdi, Fauzan, Arnawa, Anwar, \& Widada, (2019), Gee, Fauzan, \& Atmazaki, (2018), Tasman, Ahmad, \& Suher man, (2019). Hasil penelitian menyatakan siswa mencapai prestasi yang lebih baik setelah terlibat dalam proses pembelajaran RME dan dengan melalui pendekatan RME kemampuan pemecahan masalah siswa lebih baik terhadap topik pembagian (Armanto, 2002). Kemampuan pemecahan masalah yang dimaksudkan adalah kemampuan siswa dalam memecahkan masalah kontekstual yang diberikan pada pembelajaran topik pembagian.

Berdasarkan situasi di atas, maka perlu dikembangkan suatu produk pembelajaran yang 
disebut dengan Local Instructional Theory (LIT). LIT adalah teori tentang proses pembela jaran untuk suatu topik tertentu dengan aktivitas yang mendukungnya (Gravemeijer \& Eerde, 2009). LIT yang dikembangkan menggunakan prinsip dan karakteristik RME dengan topik pembagian untuk siswa kelas III sekolah dasar. Pada tahap awal produk yang dikembangkan adalah suatu Hypotetical Learning Trajectory (HLT). HLT berkaitan tentang dugaan guru tentang proses kognitif siswa terhadap pema haman suatu konteks yang memiliki tiga kom ponen, yaitu tujuan belajar siswa, kegiatan belajar yang akan dialami siswa, dan hipotesis tentang proses siswa selama belajar. Tiga kom ponen tersebut dilengkapi dengan antisipasi yang akan dilakukan guru terhadap hipotesis mengenai kekeliruan yang dilakukan oleh siswa (Tasman, 2011) (Gravemeijer, 2004), (Tasman, 2017), (Tasman, Ahmad, \& Suherman, 2018), (Harini \& Rosyidi, 2016). HLT inilah yang akan menjadi LIT setelah ia dicobakan di kelas.

\section{METODE PENELITIAN}

Jenis penelitian ini merupakan penelitian pengembangan. Produk yang dihasilkan berupa Local Instructional Theory (LIT) untuk topik pembagian dengan bentuk awalnya berupa Hypothetical Learning Trajectory (HLT) yang didukung oleh RPP dan LKPD. Pengembangan produk tersebut menggunakan design research yang terdiri dari tiga fase, yakni preparing for the experiment, experimenting in the classroom, dan conducting retrospective analysis(Akker, Gravemeijer, McKenney, \& Nieveen, 2006).

HLT diawali dengan thought experiment, yaitu memikirkan alur pembelajaran yang akan dilalui siswa dan kemudian melakukan ujicoba di kelas (instruction experiment) dan dilakukan refleksi terhadap hasil pelaksanaan tersebut. Jika tujuan belum tercapai maka dilanjutkan dengan thought experiment dan instruction experiment berikutnya pada materi yang sama. Hubungan tersebut tergambar pada Gambar 1 (Akker et al., 2006).

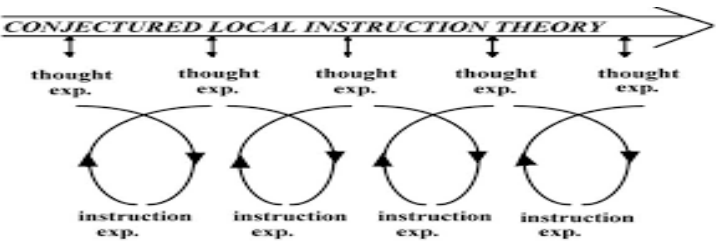

Gambar 1. Hubungan Refleksi Antara Teori Dengan Eksperimen
HLT diujicobakan kepada siswa kelas III SDN 37 Sungai Bangek yang berjumlah 18 peserta didik. Pembelajaran yang dilaksanakan didasarkan kepada HLT dan RPP yang telah diperbaiki berdasarkan uji coba pada kelompok kecil. Selain itu, selama ekperimen, ditentukan pula praktikalitas dan efektivitas dari produk. Praktikalitas produk ditentukan dari analisis lem bar observasi dan angket. Selama pembelajaran dilaksanakan, dinilai keterlaksanaan RPP mela lui lembar observasi. Kemudian, peserta didik mengisi angket di akhir pertemuan. Sementara itu, efektivitas produk diukur dengan membe rikan tes kemampuan pemecahan masalah mate matika kepada siswa di akhir pertemuan. Tes yang diberikan, sebelumnya dilakukan validasi, uji coba dan dianalisis sehingga didapatkan soalsoal yang valid dan reliabel.

Tes diberikan kepada siswa kelas III SDN 37 Sungai Bangek dan SDN 21 Sungai Bangek. Hal ini didasarkan untuk mengetahui keterca paian produk dengan membandingkan hasil tes antara siswa yang belajar menggunakan LIT dengan siswa yang belajar tidak menggunakan LIT. Efektivitas produk diketahui dengan mem bandingkan persentase kemampuan pemecahan masalah matematika siswa dan melakukan uji hipotesis. Adapun rumusan hipotesisnya adalah "Kemampuan pemecahan masalah siswa dengan menggunakan Local Instructional Theory lebih tinggi dari yang diajarkan secara konvensional".

\section{HASIL DAN PEMBAHASAN}

\section{Tahap Preparing for Experiment}

Fase ini bertujuan untuk mempersiapkan dan membuat rancangan produk yang ingin dihasilkan, yakni LIT, RPP dan LKS. Pada fase tersebut dilakukan empat tahapan, yaitu analisis kebutuhan dan konteks, tinjauan literatur, disain produk, dan evaluasi formatif. Hasil analisis kebutuhan dan konteks, terdiri atas empat bagian yaitu 1) Hasil analisis kurikulum menunjukkan topik pembagian berada pada ranah bilangan dengan standar kompetensi melakukan operasi hitung bilangan sampai tiga angka. Kompetensi dasar yang diharapkan adalah peserta didik mela kukan perkalian dan pembagian yang hasilnya berupa tiga angka. 2) Hasil analisis dari konsep menunjukkan topik pembagian yang dirancang diajarkan melalui topik pengurangan berulang, perkalian dan pembagian dengan sepuluh dan algoritma standar. 3) Hasil analisis dari siswa 
menunjukkan peserta didik menyukai a) LKS menggunakan kertas berukuran F4 dengan rotasi portrait. b) LKS menggunakan huruf tipe arial berukuran 16. c) LKS didominasi oleh warna biru. d) LKS berisi gambar berkaitan dengan alam. e) Permasalahan yang diberikan berkaitan dengan jenis pekerjaan orang tua siswa, seperti berdagang dan guru; permainan siswa, seperti permainan congklak; kegiatan dalam pembuatan keterampilan; peminjaman buku dan alat tulis; serta kegiatan menabung dan membeli mainan. 4) Hasil analisis pada lingkungan menunjukkan adanya program rutin sekolah. Program rutin yang dilakukan ialah kunjungan perpustakaan dengan membaca buku, sarapan pagi dengan membawa bekal dari rumah, dan pentas seni.

Hasil tinjauan literatur yang didasarkan dari hasil penelitian Armanto (2002) mendesain pembelajaran pembagian dengan menggunakan pengurangan berulang, terlihat bahwa siswa da pat menggunakan perkalian 10, siswa mampu menggunakan perkalian dengan kelipatan sepu luh, dan siswa dapat menggunakan algoritma standar pembagian, sedangkan Prahmana \& Suwasti (2014), Nuari, Prahmana, dan Fatma wati (2019), menyatakan pengajaran pembagian dengan pendekatan RME, yang diawali dengan permasalahan yang berkaitan dengan pembagian atau konsep terdahulu yang memiliki keterkaitan sebaiknya disajikan dengan masalah sehari-hari dan diselesaikan dengan diskusi. Selama diskusi, guru memberikan bimbingan kepada siswa. Kegiatan dilanjutkan dengan menuliskan temuan yang didapatkan dari hasil diskusi. Siswa memberikan pendapat terhadap temuan yang di dapatkan tersebut. Temuan yang didapat oleh siswa dibahas bersama dengan guru. Setelah itu, kegiatan dilanjutkan dengan permasalahan yang menggunakan bilangan yang lebih besar dari sebelumnya. Selama proses belajar, terdapat evaluasi model penyelesaian siswa dari informal ke formal.

Hasil awal dari produk berupa HLT, RPP dan LKS. HLT yang dirancang memiliki bebe rapa komponen, yakni tujuan, aktivitas, prediksi dan antisipasi guru pada setiap pertemuannya yang tertuang dalam empat pertemuan. Pada HLT pertemuan pertama tujuan yang ingin dicapai adalah peserta didik dapat menemukan hasil pembagian dengan pengurangan berulang. Aktivitas yang disediakan adalah permainan congklak. Prediksi terhadap aktivitas yang dilakukan siswa adalah 1) diperkirakan siswa akan menyelesaikan permasalahan pembagian yang diberikan, 2) sebagian siswa mungkin akan terlihat bingung atau diam saja, 3) siswa mengisi satu biji congklak pada setiap lobang dan begitu seterusnya sampai biji congklak yang disediakan habis terbagi. 4) siswa mengisi dua-dua pada setiap lobang sampai tujuh lobang terisi sama banyak, 5) mengisi langsung dengan empat biji congklak pada 7 lobangnya, 6) membuat gambar lingkaran yang terdapat lambang titik-titik atau bilangan di dalamnya yang sama, 7) siswa menu liskan hasil pengurangan secara bergantian, siswa mengurangkan semua bilangan secara berurutan ke samping atau ke bawah, dan siswa keliru menghitung pengurangannya. Prediksiprediksi yang dilakukan oleh siswa tersebut diantisipasi dengan probing question seperti a) Apakah siswa dapat menggunakan alat yang disediakan atau membuat gambar mengenai persoalan yang diberikan? b) Apakah perlu digambar dan dihitung seperti itu? c) Apakah perlu dikurangi secara bergantian seperti itu semuanya? d) Apakah perlu dikurangkan secara berurutan semuanya?

HLT pada pertemuan kedua, tujuan yang ingin dicapai adalah siswa dapat melakukan pembagian dengan perkalian 10. Aktivitas yang disediakan adalah membuat keterampilan. Dipre diksi siswa menyelesaikan permasalahan yang diberikan sama seperti sebelumnya, dan terdapat penambahan beberapa prediksi, seperti siswa menggunakan pembagian dengan melibatkan perkalian 10, siswa langsung membagi sepuluh dan sisanya dibagi lagi dengan jumlah yang sama banyak. Selain itu, bentuk antisipasi yang diberikan sama. Dalam hal ini, untuk prediksi tambahan, antisipasi yang dilakukan dengan memberikan pertanyaan pemicu.

Pada pertemuan ketiga, tujuan yang ingin dicapai ialah siswa dapat melakukan pembagian dengan kelipatan 10. Aktivitas yang diberikan berkaitan dengan aktivitas yang dilakukan di sekolah, seperti peminjaman membaca buku dan pembagian alat tulis yang dilakukan oleh guru. Prediksi yang terdapat pada pertemuan ini yakni siswa menggunakan alat yang disediakan, siswa membuat gambar seperti sebelumnya, siswa melakukan pengurangan berulang, siswa melaku kan pembagian dengan perkalian 10 , siswa keliru dalam menghitungnya. Ada beberapa anti sipasi yang sama dilakukan, namun juga ada antisipasi dengan menggunakan pertanyaan baru, seperti "Apakah kita perlu melakukan pengurangan seperti itu? Bilangan berapa saja yang merupakan kelipatan 10 ? 
Pada pertemuan keempat, tujuan yang ingin dicapai adalah siswa dapat menemukan hasil pembagian dengan algoritma standar. Aktivitas yang diberikan mengenai kegiatan menyimpan uang. Prediksi yang diberikan terha dap aktivitas ini, hampir sama dengan perte muan tiga, hanya saja terdapat prediksi baru, yakni siswa menggunakan perkalian kelipatan 10 dan sudah mulai menggunakan algoritma standar meskipun belum menyerupai prosedur yang diharapkan. Antisipasi yang dilakukan ialah memberikan pertanyaan seperti "Apakah cara lain yang lebih mudah digunakan untuk menyelesaikannya?".

RPP merupakan produk pendukung yang dibuat terhadap implementasi HLT. Ada empat RPP yang dibuat dengan didasarkan pada tujuan yang ingin dicapai. RPP tersebut dibuat berda sarkan komponen-komponen yang terdapat pada kurikulum.

Instrumen pendukung HLT lainnya adalah LKS. LKS menjadi sarana belajar siswa untuk membantu kemudahan siswa dalam memahami materi yang dipelajari. LKS dibuat dengan menggunakan kertas ukuran F4 dan isi memiliki huruf times new roman ukuran 12. Ada empat LKS yang dibuat berdasarkan pada tujuan yang ingin dicapai. Komponen pada LKS yang dibuat yakni cover LKS, kata pengantar, daftar isi, SK, $\mathrm{KD}$ dan Indikator, petunjuk belajar, dan tugastugas atau permasalahan konstektual, tujuan pembelajaran, dan evaluasi yang termuat pada LKS 1, LKS 2, LKS 3, dan LKS 4.

Hasil evaluasi formatif terdiri atas hasil self evaluation and expert review. Hasil self evaluation dapat dilihat pada Tabel 1.

Tabel 1. Hasil Self Evaluation

\begin{tabular}{|c|c|c|c|}
\hline No & $\begin{array}{c}\text { Aspek yang } \\
\text { Dievaluasi }\end{array}$ & Sebelum Revisi & Sesudah Revisi \\
\hline 1. & Kesalahan pengetikan & $\begin{array}{l}\text { HLT } \\
\text { • dilakukaen } \\
\text { - radit } \\
\text { • disekolah } \\
\text { - bekerja sama } \\
\end{array}$ & $\begin{array}{l}\text { HLT } \\
\text { - dilakukan } \\
\text { - Radit } \\
\text { - di sekolah } \\
\text { - bekerjasama } \\
\end{array}$ \\
\hline & & $\begin{array}{l}\text { RPP } \\
\text { - Dibawah } \\
\text { LKS } \\
\text { - Menyelesaikan } \\
\end{array}$ & $\begin{array}{l}\text { RPP } \\
\text { - Di bawah } \\
\text { LKS } \\
\text { - Penyelesaian } \\
\end{array}$ \\
\hline 2 & $\begin{array}{l}\text { Kesalahan penulisan } \\
\text { bahasa asing }\end{array}$ & $\begin{array}{l}\text { HLT } \\
\text { - Probing question } \\
\text { RPP } \\
\text { - Realistics Mathematics } \\
\text { Education } \\
\text { - Phenomenology } \\
\text { - Model } \\
\text { - concep }\end{array}$ & $\begin{array}{l}\text { HLT } \\
\text { - Probing question } \\
\text { RPP } \\
\text { - Realistic Mathematics } \\
\text { Education } \\
\text { - Phenomenology } \\
\text { - Models } \\
\text { - Concept }\end{array}$ \\
\hline
\end{tabular}

Tabel 1.bersambung sambungan Tabel 1.

\begin{tabular}{|c|c|c|c|}
\hline 3 & $\begin{array}{l}\text { Relevansi } \\
\text { permasalahan dan } \\
\text { ilustrasi gambar yang } \\
\text { diberikan }\end{array}$ & $\begin{array}{l}\text { LKS } \\
\text { - Tidak ada gambar anak } \\
\text { yang menceritakan } \\
\text { permasalahan } \\
\text { - Gambar beras }\end{array}$ & $\begin{array}{l}\text { LKS } \\
\text { - Terdapat gambar anak } \\
\text { yang menceritakan } \\
\text { permasalahan. } \\
\text { - Gambar karung beras }\end{array}$ \\
\hline 4 & $\begin{array}{l}\text { Ketepatan } \\
\text { tulisan }\end{array}$ & $\begin{array}{l}\text { LKS } \\
\text { - Ukuran judul LKS 1,2, } \\
\text { 3, dan } 4 \text { berbeda serta } \\
\text { penulisan aktivitas kecil } \\
\text { (12) }\end{array}$ & $\begin{array}{l}\text { LKS } \\
\text { - Ukuran judul LKS 1, } \\
\text { 2, 3, dan } 4 \text { serta } \\
\text { penulisan aktivitas } \\
\text { diperbesar (16) }\end{array}$ \\
\hline 5 & $\begin{array}{lr}\text { Ketersediaan tempat } \\
\text { jawaban } \\
\text { menyelesaikan masalah } \\
\text { yang diberikan }\end{array}$ & $\begin{array}{l}\text { LKS } \\
\text { - Baris-baris } \\
\text { disediakan yang } \\
\text { memadai dan } \\
\text { teratur }\end{array}$ & $\begin{array}{l}\text { LKS } \\
\text { - Baris-baris yang } \\
\text { disediakan dibuat } \\
\text { memadai dan teratur }\end{array}$ \\
\hline
\end{tabular}

Validasi oleh expert dilakukan oleh tiga orang pakar terhadap produk yang telah dibuat, yaitu 1 orang dosen matematika UNP, 1 orang dosen Bahasa Indonesia UNP, dan 1 orang dosen Seni UNP. Hasil validasi HLT dari aspek isi oleh ahli matematika menunjukkan nilai 100 dengan kategori sangat valid. Sedangkan dari aspek Bahasa oleh ahli bahasa memiliki nilai 92,5 yang juga menunjukan kategori sangat valid. Hasil validasi berupa perubahan terhadap HLT, RPP dan LKS dapat dilihat pada Tabel 2.

Tabel 2. Hasil Validasi HLT

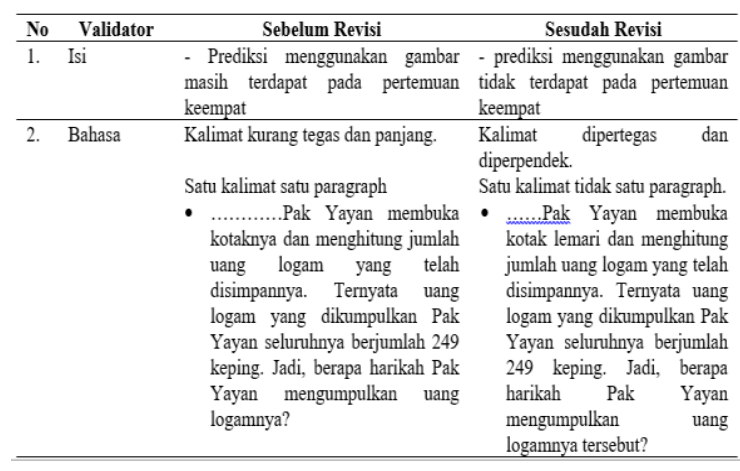

Hasil validasi menunjukkan bahwa RPP dan LKS juga memiliki kategori sangat valid. Perubahan RPP setelah validasi dapat dilihat pada Tabel 3, sedangkan perubahan pada LKS setelah validasi dapat dilihat pada Tabel 4 .

Tabel 3. Perubahan RPP Setelah Validasi

\begin{tabular}{ccll}
\hline No & Validator & \multicolumn{1}{c}{ Sebelum Revisi } & \multicolumn{1}{c}{ Sesudah Revisi } \\
\hline 1. & Isi & Langkah-langkah menggambarkan & Langkah-langkah menggambarkan \\
& & kegiatan guru. & kegiatan siswa. \\
& Contoh: & Contoh: \\
& Guru bersama siswa melakukan & Siswa bersama guru melakukan \\
& tanya jawab mengenai & Tanya jawab mengenai \\
& permasalahan tersebut. & permasalahan tersebut. \\
\hline & Kegiatan RME kurang tergambar & Kegiatan RME tergambar \\
& - probing question tidak & - probing question telah \\
& dituangkan dalam langkah- & dituangkan dalam langkah- \\
& langkah pembelajaran & langkah pembelajaran \\
\hline & & Langkah pembelajaran diarahkan & Langkah pelajaran diarahkan pada \\
& pada kegiatan guru. & kegiatan siswa.
\end{tabular}


Tabel 4. Perubahan LKS Setelah Validasi

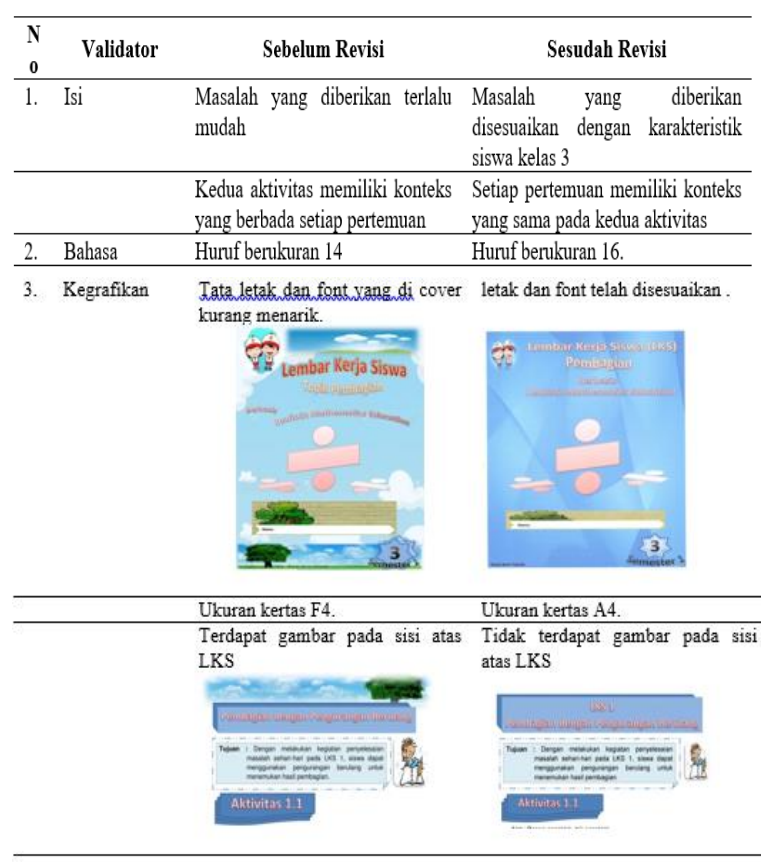

\section{Tahap experimenting in the classroom}

Pada pertemuan pertama, peserta didik diharapkan mampu menemukan hasil pemba gian dengan pengurangan berulang. Peserta didik diberikan 28 anak conglak dan mereka diminta menentukan masing masing isi lobang pada congklak. Persoalan tersebut dalam dalam matematikanya dapat dinyatakan dalam 28 dibagi 7. Gambar-gambar berikut memperlihat kan beberapa jawaban peserta didik pada LKS mereka.

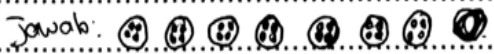

$44{ }_{4} 4{ }_{4} 4$

Gambar 2. Jawaban Peserta Didik A

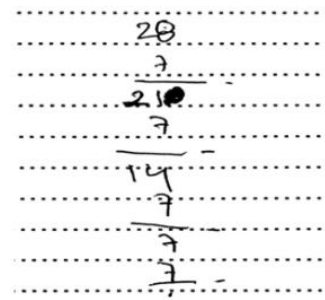

Gambar 3. Jawaban Peserta Didik B

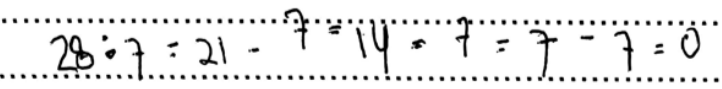

Gambar 4. Jawaban Peserta Didik C
Dari ketiga gambar di atas terlihat bahwa para peserta didik telah melakukan pengurangan berulang. Akan tetapi peserta didik A dapat membuat model situasi dari congclak dengan menggambarkan congclak tersebut, dan terlihat juga bahwa siswa berlebih menggambar lobang congclaknya sehingga dapat dilihat pada gambar siswa menghapus satu lubang. Peserta didik A juga menulis isi dari masing-masing congclak yang berjumlah 4 .

Berbeda dengan peserta didik A, peserta didik $\mathrm{B}$ dan $\mathrm{C}$ tidak menggunakan model dari congclak, tetapi mereka menggunakan bilangan. 28 menggambarkan banyaknya anak congclak dan 7 menyatakan banyaknya lubang congclak. Peserta didik $\mathrm{B}$, menggambarkan pengurangan berulang ke bawah dengan menggunakan simbol matematika yang tepat. Sedangkan peserta didik $\mathrm{C}$, melakukan pengurangan berulang kesamping, akan tetapi terdapat kekeliruan dengan tanda sama dengan yang dituliskan yang jelas secara matematika penggunaan tanda sama dengan "=" dalam kasus ini adalah hal yang salah. Akan tetapi kedua jawaban siswa tersirat bahwa proses pengurangan 7 dilakukan selama 4 kali dan tidak menyisakan anak congclak. Dilihat dari ketiga jawaban perserta didik, hanya peserta didik A yang memberikan jawaban terhadap persoalan secara langsung dengan menuliskan angka 4 yang menunjukkan masing-masing lu bang berisi 4 congclak, sedangkan peserta didik $\mathrm{B}$ dan $\mathrm{C}$ tidak memberikan jawaban tersebut.

Pada pertemuan kedua, peserta didik diharapkan dapat menemukan hasil pembagian dengan pengurangan berulang. Peserta didik diberikan permasalahan mengenai pembuatan keterampilan dari stik es. Permasalahan yang di berikan kepada peserta didik adalah sebagai berikut.

Untuk membuat mainan kunci, diperlukan 8 batang stik es, jika Lina memiliki 104 buah stik es. Berapakah banyak mainan kunci yang dapat di buat oleh Lina?

Salah satu jawaban peserta didik dapat dilihat pada Gambar 5.

Berdasarkan Gambar 5, terlihat bahwa peserta didik dapat menyelesaikan permasalahan dengan melakukan pengurangan berulang dan menghitung berapa kali banyaknya pengurangan berulang yang dilakukan sehingga menemukan jawaban 13 . 


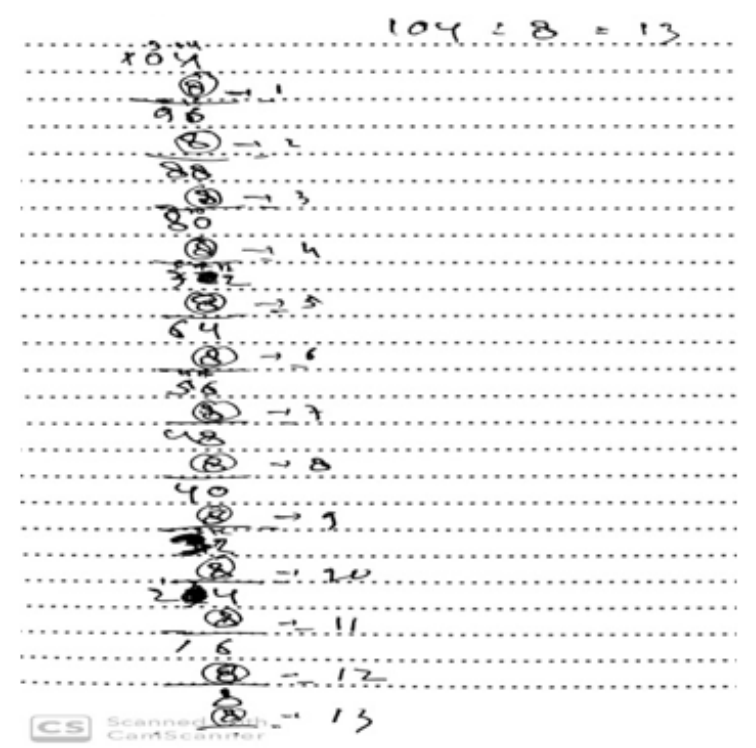

Gambar 5. Jawaban Peserta Didik A

Berbeda dengan peserta didik A, peserta didik B menyelesaikan persoalan sudah menggunakan basis 10 , yang merupakan tujuan pembelajaran untuk pertemuan ketiga. Jawaban peserta didik B dapat dilihat pada Gambar 6 .

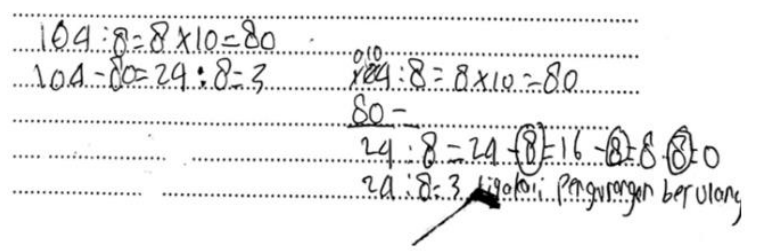

Gambar 6. Jawaban Peserta Didik B

Berdasarkan Gambar 6, dapat dilihat bah wa peserta didik B menyelesaikan permasalahan dengan baik dengan memanfaatkan pengeta huannya tentang perkalian bilangan dengan 10 . Kemudian peserta didik B, mengurangkan 104 dengan 80 dan dapatkan sisa 24 , kemudian sisanya yang 24 dibagi lagi dengan 8 dan peserta didik tersebut menuliskan bahwa itu tiga kali pengurangan berulang, sehingga ia mendapatkan jawaban 10 ditambah 3 yaitu 13. Jawaban dari peserta didik B dipresentasikan di depan kelas, bagaimana cara ia mendapatkan idenya.

Pada pertemuan ketiga dengan tujuan peserta didik dapat menemukan hasil pembagian dengan kelipatan 10. Peserta didik diberikan permasalahan sebagai berikut.

Suatu hari, ibu guru Tati membawa banyak sekali buku cerita bergambar ke sekolah. Buku-buku yang dibawa ibu guru, semuanya berjumlah 112 buku. Buku itu kemudian dipinjamkan kepada peserta didik untuk dibaca.
Apabila setiap peserta didik mene rima masing-masing 4 buku sama banyak, berapakah jumlah peserta didik yang meminjam buku dari ibu Tati?

Beberapa jawaban peserta didik terhadap permasalahan dapat dilihat pada Gambar 7 dan Gambar 8.

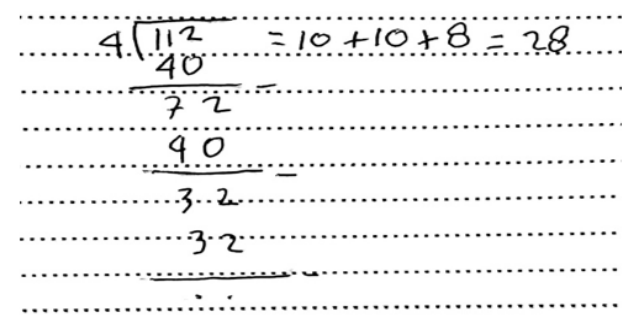

Gambar 7. Jawaban Peserta Didik A

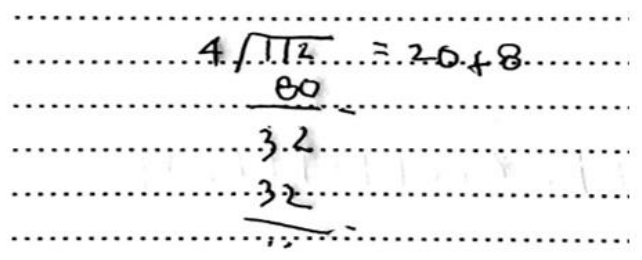

Gambar 8. Jawaban Peserta Didik B

Dari Gambar 7, terlihat bahwa peserta didik A, sudah menjawab dengan pengulangan berulang dengan menggunakan basis 10. Terlihat peserta didik A terpengaruh oleh ide dari temannya yang di presentasikan pada minggu sebelumnya. Hal ini memperlihatkan salah satu ciri dari RME adalah adanya student contribution. Kontribusi dari peserta didik pada minggu sebelumnya tentang ide dari basis 10 dapat mempercepat perhitungan sangat membantu siswa lain untuk meningkatkan kemampuannya dalam menyele saikan masalah.

Berbeda dari peserta didik A, peserta di dik B sudah lebih baik dalam menyelesaikan persoalan, ia bahkan dapat langsung mengguna kan kelipatan 10 terdekat (dalam hal ini 20) untuk menemukan hasil yang lebih cepat lagi. Peserta didik B, diminta untuk membagi idenya mengapa dia menggunakan 20 di depan kelas. Hal ini sangatlah penting karena ini merupakan dasar ide dari penggunaan algoritma standar.

Pada pertemuan keempat dengan tujuan peserta didik dapat menentukan hasil pembagian dengan algoritma standar, peserta didik diberi kan permasalahan sebagai berikut.

Setiap hari, pak Yayan selalu mema sukkan 3 keping uang logam kedalam 
kotak lemarinya. Tidak pernah satu haripun pak Yayan lupa untuk menyi sihkan uang logamnya. Pada suatu hari pak Yayan membuka kotaknya dan menghitung jumlah uang logam yang telah ia simpan. Ternyata uang logam yang telah dikumpulkan pak Yaya nada sebanyak 249 keping. Berapa lamakah pak Yayan mengum pulkan uangnya?

Pada Gambar 9 memperlihatkan jawaban peserta didik A terhadap permasalahan tersebut.

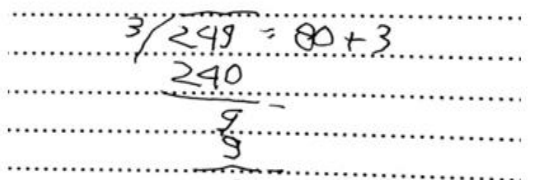

Gambar 9. Jawaban Peserta Didik A

Berdasarkan Gambar 9, peserta didik A, sudah menyelesaikan persoalan dengan baik. Akan tetapi, algoritma yang dia tulis masih belum dalam bentuk standar. Untuk sampai kepada bentuk standar, bimbingan dari guru sangatlah diperlukan.

Setelah diskusi kelas, guru memberikan persoalan lain kepada siswa dengan mengganti banyaknya koin, yaitu sebanyak 175 koin dan ditabung 7 koin setiap hari. Pada Gambar 10 memperlihatkan salah satu jawaban siswa.

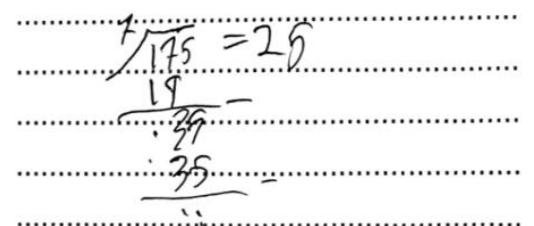

Gambar 10. Jawaban Peserta didik A

Pada Gambar 10, terlihat peserta didik sudah dapat menyelesaikan persoalan tersebut dengan menggunakan algoritma standar. Pemahaman akan nilai tempat menjadi bagian yang sangat penting untuk sampai kepada tahap akhir dari pembagian dengan menggunakan algoritma standar.

\section{Tahap Retrospective Analysis}

Pembelajaran untuk topik pembagian di Indonesia diajarkan dengan bilangan decimal, dalam hal ini bilangan bulat, yang sama dengan Jepang (Kim \& Pang, 2018). Untuk itu, pada tahap experimenting in the classroom bilangan yang digunakan adalah pembagian bilangan dua digit dengan satu digit dan pembagian bilangan tiga digit dengan satu digit.

Pada tahap experimenting ini dugaandugaan yang telah dibuat pada tahap preparing, terlihat terlaksana walaupun ada dari proses kognitif siswa yang berada di luar dugaan. Seperti pada pertemuan kedua, ada peserta didik yang bahkan sudah mendapatkan ide untuk membagi menggunakan basis 10. Dari tahap ekperimen di kelas, dapat dilihat bahwa, ide matematis dalam pembelajaran pembagian ini, pengurangan berulang, pengurangan berulang dengan basis 10 , pembagian dengan mengguna kan algoritma standar. Hal ini sejalan dengan Fosnot \& Dolk (2001). Proses pemahaman siswa tentang algoritma pembagian harus dibangun dengan pengulangan berulang, siswa harus di sadarkan bahwa mereka memerlukan strategi untuk membagi lebih cepat. Hal ini memuncul kan strategi pembagian dengan kelipatan 10 . Dari strategi kelipatan $10 \mathrm{ke}$ algoritma standar diperlukan pemahaman konsep nilai tempat. Sehingga para peserta didik akan memahami konsep dan gagasan algoritma standar. Proses numerasi ini harus dipahami dengan baik oleh pendidik maupun calon pendidik (Chapman, 2011). Permasalahan kontekstual (Nuari et al., 2019) dan pendekatan RME mendukung proses kognisi siswa untuk membagun pemahamannya tentang algoritma standar pembagian (Prahmana \& Suwasti, 2014). RME memberikan peluang peserta didik untuk belajar melalui peserta didik yang lain. Hal ini karena kemampuan kognitif yang berbeda tentu akan menimbulkan strategi pemecahan masalah pembagian yang berbeda (Schulz \& Leuders, 2018).

\section{Praktikalitas}

Lembar observasi keterlaksanaan RPP berbasis RME, menunjukan nilai rata-rata 91,07 dengan kategori sangat praktis. Seperti yang ditunjukkan olah Tabel 5.

\section{Tabel 5. Praktikalitas RPP RME}

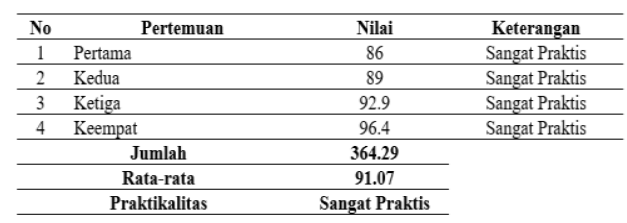

LKS yang telah dirancang dan dicobakan juga berada pada kategori yang sama. LKS menunjukan nilai 89,06 dengan kategori sangat praktis seperti yang terlihat pada Tabel 6 . 
Tabel 6. Praktikalitas LKS

\begin{tabular}{|c|c|c|c|c|c|c|}
\hline $\begin{array}{l}\mathbf{N} \\
\mathbf{0}\end{array}$ & Indikator & $\begin{array}{c}\text { Nomor } \\
\text { Pernyataan }\end{array}$ & $\begin{array}{c}\text { Jumlah } \\
\text { Skor }\end{array}$ & $\begin{array}{c}\text { Skor } \\
\text { Maksimal }\end{array}$ & Nilai & Praktikalitas \\
\hline 1 & Penyajian LKS & 1,2 & 131 & 144 & 90.97 & Sangat praktis \\
\hline 2 & $\begin{array}{l}\text { Keterbacaan atau } \\
\text { bahasa }\end{array}$ & 3,4 & 136 & 144 & 94.44 & Sangat praktis \\
\hline 3 & $\begin{array}{l}\text { Kemudahan } \\
\text { penggunaan }\end{array}$ & $5,6,7,8,9,10$ & 366 & 432 & 84.72 & Sangat praktis \\
\hline \multirow[t]{4}{*}{4} & $\begin{array}{l}\text { Kesesuaian waktu } \\
\text { yang digunakan }\end{array}$ & 11 & 62 & 72 & 86.11 & Sangat praktis \\
\hline & & Jumlah & & & 356.25 & \\
\hline & & Rata-rata & & & 89.06 & \\
\hline & & Kategori & & & $\begin{array}{l}\text { Sangat } \\
\text { Praktis }\end{array}$ & \\
\hline
\end{tabular}

Efektivitas

Keefektifan produk terlihat dari hasil tes yang diberikan. Perbandingan dilakukan antara siswa kelas III SDN 37 Sungai Bangek yang diberikan pembelajaran dengan menggunakan LIT sebagai kelas eksperimen dengan siswa kelas III SDN 21 Sungai Bangek menggunakan pembelajaran secara konvensional sebagai kelas kontrol.

Berdasarkan hasil tes kemampuan peme cahan masalah, terdapat perbedaan kemampuan pemecahan masalah matematika siswa kelas eksperimen dengan siswa kelas kontrol. Hasil analisis menunjukan bahwa kemampuan kelas eksperimen $83,33 \%$ (efektif), sementara kemam puan kelas kontrol 69,38\% (cukup efektif). Selisih perbedaan kedua kemampuan tersebut ialah $13,95 \%$. Hal tersebut menunjukan bahwa rangkaian aktivitas belajar dengan menggunakan LIT berbasis RME memberikan dampak yang baik terhadap kemampuan pemecahan masalah matematika siswa.

Hasil uji statistika terhadap data kedua kelas menunjukkan bahwa $\mathrm{H}_{1}$ diterima, yaitu $\mathrm{t}$ hitung > t tabel, yang berarti bahwa kemampuan pemecahan masalah matematika siswa dengan menggunakan LIT lebih tinggi dari yang diajar secara konvensional.

\section{KESIMPULAN}

Hasil validasi menunjukkan LIT valid yang terlihat dari aspek isi, bahasa, didaktik, dan penyajian yang sesuai dengan prinsip dan karakteristik RME. Hal ini terlihat dari proses validasi pakar pembelajaran dan bahasa yang menyatakan bahwa pembelajaran yang diran cang telah memiliki konteks dan sesuai dengan karakteristik siswa kelas 3 sekolah dasar dan telah menggunaan kaidah bahasa yang baik sehingga tujuan pembelajaran dapat tercapai. Hasil uji coba juga menunjukan kategori sangat praktis yang terlihat dari segi kemudahan peng gunaan, keterbacaan siswa dan ketersediaan waktu sehingga siswa dapat melakukan serang kaian aktivitas belajar LIT. Selain itu, LIT berdampak pada kemampuan pemecahan masa lah siswa yang efektif. Hal ini terlihat dari perbandingan rata-rata kemampuan pemecahan masalah matematika siswa yang menggunakan LIT dengan tidak menggunakan LIT. Uji hipo tesis menunjukkan kemampuan pemecahan masalah siswa yang belajar dengan mengguna kan LIT lebih baik dari pada siswa yang diajarkan topik pembagian dengan metode konvensional.

\section{DAFTAR PUSTAKA}

Akker, J. Van den, Gravemeijer, K., McKenney, S., \& Nieveen, N. (2006). Introducing Edu cational Design Research. Educational De sign Research, (2004), 1-163.

Antari, L. (2015). Penggunaan Bahan Ajar Tema tik Pembagian Untuk Meningkatkan Hasil Belajar Di Kelas IIa MI Ahliyah II Palem bang. AKSIOMA Journal of Mathematics Education, 4(2), 22-29.

https://doi.org/10.24127/ajpm.v4i2.307

Armanto, D. (2002). Teaching multiplication and division realistically in Indonesian primary schools : a prototype of local ins tructional theory. 309. Retrieved from http://doc.utwente.nl/58710/1/thesis_Arma nto.pdf

Chapman, O. (2011). International Symposium Elementary Maths Teaching: Prospective Elementary School Teachers' Learning Tra jectory of Numerical System. In Education (pp. 138-147).

Fosnot, C. T., \& Dolk, M. (2001). Young mathe maticians at work: Constructing multiplica tion and division.

Freudenthal, H. (1986). Didactical phenomenolo gy of mathematical structures (Vol. 1). Springer Science \& Business Media.

Gee, E., Fauzan, A., \& Atmazaki, A. (2018). Designing learning trajectory for teaching sequence and series using RME approach to improve students' problem solving abilities. Journal of Physics: Conference Series, 1088. https://doi.org/10.1088/17426596/1088/1/012096

Gravemeijer, K. (2004). Local instruction theo ries as means of support for teachers in reform mathematics education. Mathemati cal Thinking and Learning, 6(2), 105-128.

Gravemeijer, K., \& Van Eerde, D. (2009). Design research as a means for building a 
knowledge base for teachers and teaching in mathematics education. Elementary School Journal, 109(5), 510-524 https://doi.org/10.1086/596999

Harini, A.R., \& Rosyidi, A. H. (2016). Lintasan Belajar Siswa pada Materi Jajargenjang dengan Metode Penemuan Terbimbing melalui Penelitian Desain. Jurnal Ilmiah Pendidikan Matematika, III (5), 28-37. Re trieved from https://jurnalmahasiswa.unesa .ac.id/index.php/mathedunesa/article/view/ 18508

Hasan, Q. A. (2012). Pengembangan Pembela jaran Operasi Pembagian. (November), 978-979.

Henik, A. (2016). Continius Issues in Numerical Cognition. In Continuous Issues in Nume rical Cognition: How Many or How Much. https://doi.org/10.1016/B978-0-12801637-4.00004-4

Kim, J. W., \& Pang, J. S. (2018). A comparative analysis of division in elementary mathe matics textbooks in Korea and Japan. Eura sia Journal of Mathematics, Science and Technology Education, 14(3), 811-822. https://doi.org/10.12973/ejmste/80946

Nuari, L. F., Prahmana, R. C. I., \& Fatmawati, I. (2019). Learning of division operation for mental retardations' student through math gasing. Journal on Mathematics Educa tion, 10(1), 127-142. https://doi.org/10.22 342/jme.10.1.6913.127-142

Prahmana, R. C. I., \& Suwasti, P. (2014). Local instruction theory on division in mathema tics gasing: The case of rural area's student in Indonesia. Journal on Mathematics Education, 5(1), 17-26. https://doi.org/10. 22342/jme.5.1.1445.17-26

Schulz, A., \& Leuders, T. (2018). Learning trajectories towards strategy proficiency in multi-digit division - A latent transition analysis of strategy and error profiles. Learning and Individual Differences, 66 (October 2016), 54-69. https://doi.org/ 10.1016/j.lindif.2018.04.014

Syafriafdi, N., Fauzan, A., Arnawa, I. M., Anwar, S., \& Widada, W. (2019). The tools of mathematics learning based on realistic mathematics education approach in elementary school to improve math abilities. Universal Journal of Educational Research, 7(7), 1532-1536. https://doi.org/ 10.13189/ujer.2019.070707

Tasman, F. (2017). Supporting Second Graders' on Learning Multiplication: A Research On Design In Primary School (1st ed.). Retrieved from https://www.morebooks.de /store/fr/book/supporting-second-graderson-learning-multiplication/isbn/978-3-33007867-3

Tasman, F., Ahmad, D., \& Suherman. (2019). The use of GeoGebra to help students gain better understanding to definition of defi nite integral. Journal of Physics: Confe rence Series, 1317, 12114. https://doi.org/ 10.1088/1742-6596/1317/1/012114

Tasman, F., Ahmad, D., \& Suherman, S. (2018). Kesulitan Mahasiswa Dalam Mengkoneksi kan Sigma, Area, dan Definisi Integral Tentu Secara Geometri. Jurnal Eksakta Pendidikan (Jep), 2(2), 186. https://doi. org/10.24036/jep/vol2-iss2/238

Tasman, F., Den Hertog, J., Zulkardi, \& Hartono, Y. (2011). Helping students acqu ainted with multiplication in rectangular model. Journal on Mathematics Education, 2(2), 185-198. https://doi.org/10.22342/jm e.2.2.747.185-198 